\title{
Diferenciação Sintomatológica de Manchas Foliares em Eucalyptus spp. Causadas por Patógenos Fúngicos e Bacterianos
}

\author{
Reginaldo G. Mafia \& Acelino C. Alfenas \\ Departamento de Fitopatologia, Universidade Federal de Viçosa, UFV, CEP 36571-000, Viçosa, MG, e-mail: aalfenas@ufv.br
}

(Aceito para publicação em 22/07/2003)

Autor para correspondência: Acelino C. Alfenas

\begin{abstract}
Differentiation of three leaf blight diseases of Eucalyptus spp., caused by fungal and bacterial pathogens

Differentiation of three leaf diseases on Eucalyptus

spp. caused by Cylindrocladium spp., Phaeophleospora epicoccoides and bacterial pathogens is described for diagnosis and quantification purposes.
\end{abstract}

Atualmente, manchas foliares causadas por patógenos fúngicos e bacterianos têm assumido grande importância, sobretudo nos viveiros de propagação clonal de eucalipto (Eucalyptus spp.). Em mudas seminais ou clonais de eucalipto é comum a ocorrência de lesões foliares causadas por espécies de Cylindrocladium, ativas ou inativas, facilmente confundíveis com àquelas causadas por bactérias e por Phaeophleospora epicoccoides (Cooke \& Massee) Crous, Ferreira \& Sutton. Através de inoculação artificial de mudas com 60 dias, com uma suspensão de esporos a $10^{5}$ conídios/ml e acompanhamento periódico do desenvolvimento das lesões, observou-se que inicialmente as lesões causadas por espécies de Cylindrocladium ocorrem ao acaso, inicialmente como pequenos pontos arroxeados que rapidamente evoluem para manchas circulares com a manutenção da coloração nos bordos e de centro amarronzado na face adaxial (Figura 1A). Com o desenvolvimento, as manchas tornam-se irregulares e na face abaxial é possível observar a formação de um halo de tom esverdeado mais escuro que o do tecido foliar sadio. A partir daí, por motivo desconhecido, algumas manchas tornam-se estéreis e assumem coloração uniformemente amarronzada clara, facilmente distinguível das lesões ativas através da visualização da folha contra a luz. A diagnose da doença é completada a partir da visualização da esporulação cristalina (Figura 1B) e das estruturas típicas do patógeno (Figura 1C), especialmente sob tecido foliar lesionado mantido em condição de alta umidade. As lesões causadas por P. epicoccoides apresentam coloração similar às causadas por espécies de Cylindrocladium, no entanto, é possível realizar a distinção através do formato da lesão, que neste caso é angular (Figura 1D) e visualização de cirros conidiais (Figura 1E), que se apresentam como pequenos pontos negros na face abaxial da folha, exsudados a partir de picnídios (Figura 1F). Diferentemente das manchas causadas pelos patógenos fúngicos, as lesões bacterianas são angulares (Figura 1G) e quando no início exibem uma coloração esverdeada escura uniforme e encharcada (Figura 1H), em ambos os lados da folha, concentrado na nervura principal e nos bordos foliares, que após o ressecamento tendem a se tornar amarronzadas. Em diagnose com suspeita de etiologia bacteriana é sempre recomendado realizar o teste de exsudação em gota, visando observar a formação de pus bacteriano (Figura 1I). O conhecimento do padrão sintomatológico das manchas foliares causadas por patógenos fúngicos e bacterianos, incluindo a distinção entre as lesões ativas e inativas é necessário para fornecer subsídios à correta diagnose e evitar a superestimação de doença causada por um determinado patógeno.

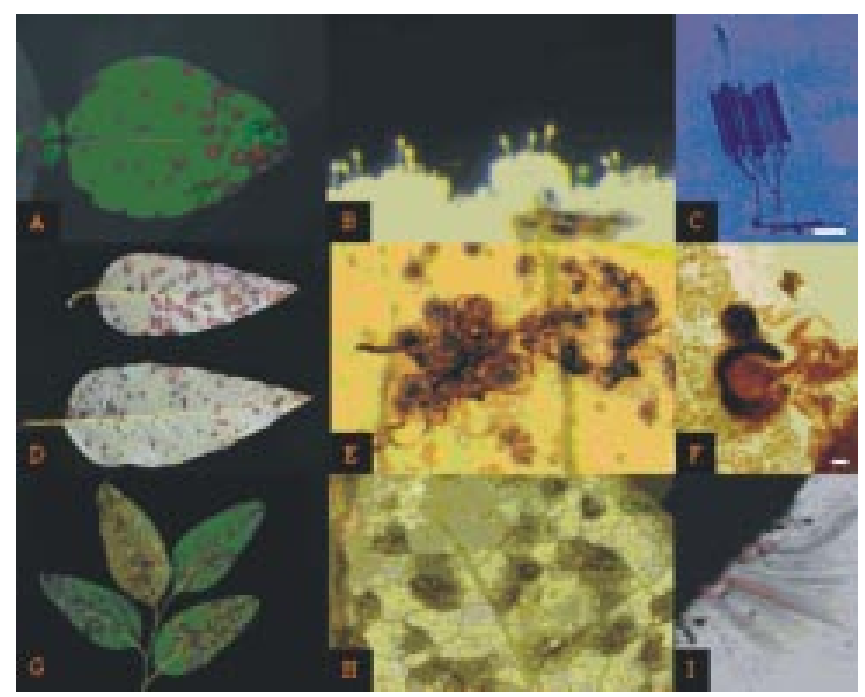

FIG. 1 - Diferenciação sintomatológica de manchas foliares em eucalipto (Eucalyptus spp.) causadas por Cylindrocladium sp. (A, B e C), Phaeophleospora epicoccoides (D, E e F) e fitobactérias (G, H e I): (A) lesões circulares dispersas ao acaso de bordos arroxeados e centro amarronzado; (B) esporulação cristalina; (C) conidióforos e conídios típicos; (D) lesões angulares com pontos negros na superfície abaxial; (E) cirros conidiais; (F) picnídios com exsudação de conídios; (G) manchas angulares concentradas em torno da nervura principal; $(\mathrm{H})$ lesão de coloração verde escuro e de aspecto encharcado; (I) presença de pus bacteriano em teste de exsudação em gota. Barras $=30 \mu \mathrm{m}$. 